\title{
PENGENALAN, PEMANTAUAN DAN PENYULUHAN PENTINGNYA PERSONAL HIGIENE DI SMAN X PEKANBARU
}

\author{
Siti Juariah $^{1}$, Eli Yusrita ${ }^{1}$, Darmadi ${ }^{1}$, Mega Pratiwi Irawan ${ }^{1}$, Ilham Kurniati ${ }^{1}$ \\ ${ }^{1}$ Akademi Analis Kesehatan Pekanbaru \\ Email: sitijuariah@univrab.ac.id / siti.juariah1005@gmail.com
}

\begin{abstract}
ABSTRAK
Hygiene diartikan sebagai ilmu yg berkenaan dengan masalah kesehatan dan berbagai usaha untuk mempertahankan atau memperbaiki kesehatan.kebersihan lingkungan merupakan salah satu faktor yang sangat mempengaruhi tingkat kesehatan bagi lingkungan dan individu. Pemahaman tentang hygiene masih dikategorikan cukup, hal ini dapat terlihat dari kebiasaan anak-anak yang selalu membuang sampai sembarangan. Tujuan kegiatan ini ialah untuk memberikan pemahaman terhadap pentingnya menjaga kesehatan dan mendeteksi tingkat kebersihan terhadap siswa-sekolah menengah atas. Metode yang digunakan ialah berupa pemantauan kebersihan lingkungan dan penyuluhan. Hasil yang diperoleh menunjukkan bahwa lingkungan sekolah menengah atas sudah masuk dalam kategori cukup bersih namun ada beberapa hal yang harus dibenahi yakni pengetahuan terhadap pentingnya menjaga kesehatan serta dampak yang akan diperoleh jika tidak bisa mengendalikan kebersihan secara berkesinambungan.
\end{abstract}

Keyword : personal hygiene, pengenalan, pemantauan, penyuluhan, Kesehatan

\begin{abstract}
Hygiene is defined as a science that deals with health problems and various efforts to maintain or improve health. Environmental cleanup is one of the factors that greatly affect the level of health for the environment and individuals. Understanding of hygiene is still categorized enough, it can be seen from the habits of children who always throw up till haphazard. The purpose of this activity is to provide an understanding of the importance of maintaining health and detecting the level of cleanliness of high school students. The method used is the monitoring of environmental hygiene and counseling. The results show that high school environments are categorized as clean enough but there are several things that must be addressed, namely the knowledge of the importance of maintaining health and the impact that will be obtained if it can not control hygiene on an ongoing basis.
\end{abstract}

Key word: personal hygiene, introduction, monitoring, counseling, health 


\section{PENDAHULUAN}

Penyakit yang disebabkan oleh kelalaian menjaga kebersihan diri sendiri (Personal hygiene) masih menjadi permasalahan kesehatan masyarakat di Indonesia terutama pada kalangan berpengetahuan minim tentang menjaga kesehatan melalui kebersihan diri. Prevalensi kebiasaan mengabaikan kebersihan diri sendiri banyak dijumpai pada anak-anak usia sekolah mulai dari usia dini hingga usia remaja. Pola kebiasaan memebrsihkan diri sangat mendukung terciptanya lingkungan yang bersih serta berakibat pada tingkat kesehatan individu. Tingkat kontaminasi tersebut bisa berasal dari makanan ataupun peraatan lannya yang berhubungan dengan individu tersebut.

SMAN X Pekanbaru yang merupakan salah satu lokasi yang dijadikan objek pemerikasan personal hygiene. Berdasarkan analisis situasi bahwa sekolah ini belum pernah mendapatkan pemeriksaan personal hygiene. Sehingga dengan demikian kami bermaksud untuk melakukan pemeriksaan terhadap siswa/siswi dilingkungan sekolan SMAN X untuk mengetahui tingkat kebersihannya.

Kebersihan diri (Personal hygiene) yang buruk dapat meningkatkan resiko terinfeksi berbagai macam penyakit terutama pada anak-anak usia sekolah. Pada usia tersebut, anakanak masih aktif bermain terutama diluar ruangan yang memungkinkan anak kontak dengan benda-benda yang banyak mengandung kuman-kuman penyebab penyakit.

Kontaminasi yang diperoleh dari tanah maupun benda-benda lain yang tidak bersih menjadi sumber utama penyebab terinfeksi penyakit. Kurangnya penerapan kebersihan diri seperti membiasakan mencuci tangan setelah bermain, sebelum dan sesudah makan juga menambah resiko masuknya berbagai penyakit kedalam tubuh. memberikan pemahaman terhadap siswa-siswi SMAN X Pekanbaru terhadap pentingnya menjaga kesehatan

\section{TINJAUAN PUSTAKA}

Menurut (Kamus Besar Bahasa Indonesia, 2008), hygiene diartikan sebagai ilmu yg berkenaan dengan masalah kesehatan dan berbagai usahauntuk mempertahankan atau memperbaiki kesehatan. Personal hygiene berasaldari bahasa Yunani yaitu personal artinya perorangan dan hygiene berarti sehat.Higiene perorangan adalah tindakan memelihara kebersihan dan kesehatanseseorang untuk kesejahteraan fisik dan psikis (Tarwoto, 2010).Higiene perorangan merupakan ciri berperilaku hidup sehat. Beberapa kebiasaanberperilaku hidup sehat antara lain kebiasaan mencuci tangan dengan sabunsetelah BAB dan kebiasaan mencuci tangan dengan sabun sebelum makan.Peningkatan higiene perorangan adalah salah satu dari program pencegahan yakni perlindungan diri terhadap penularan tifoid (DepkesRI, 2006)

Mencuci tangan merupakan proses pembuangan kotoran dan debu secara mekanis dari kedua belah tangan dengan memakai sabun dan air. Tujuan mencuci tangan adalah untuk menghilangkan kotoran dan debu secara mekanis dari permukaan kulit dan mengurangi jumlah mikroorganisme (Linda, 2004). Mencuci tangan juga dapat menghilangkan sebagian besar virus yang menjadi penyebab berbagai penyakit, terutama penyakit yang menyerang saluran cerna, seperti diare dan saluran nafas seperti influenza. Hampir semua orang mengerti pentingnya mencuci tangan memakai sabun, namun masih banyak yang tidak membiasakan diri untuk melakukan dengan benar pada saat yang penting (Achmadi, 2009)

Tangan yang kotor atau terkontaminasi dapat memindahkan bakteri atau virus patogen dari tubuh, feses atau sumber lain ke makanan. Olehkarenanya kebersihan tangan dengan mencuci tangan perlu mendapat prioritastinggi, walaupun hal tersebut sering disepelekan (Fathonah, 2005). Kegiatan mencuci tangan sangat penting untuk bayi, anak-anak, penyaji makanan di restoran, atau warung serta orang-orang yang merawat danmengasuh anak. Setiap tangan yang kontak dengan feses, urine atau dubursesudah buang air besar (BAB) maka harus 
dicuci pakai sabun dan kalau dapatdisikat (Depkes RI, 2006). Pencucian dengan sabun sebagai pembersih,penggosokkan dan pembilasan dengan air mengalir akan menghanyutkan partikelkotoran yang banyak mengandung mikroorganisme (Fathonah, 2005).

Kebersihan tangan sangatlah penting bagi setiap orang. Kebiasaan mencuci tangan sebelum makan harus dibiasakan. Pada umumnya ada keengganan untuk mencuci tangan sebelum mengerjakan sesuatu karena dirasakan memakan waktu, apalagi letaknya cukup jauh. Dengan kebiasaan mencuci tangan, sangat membantu dalam mencegah penularan bakteri dari tangan kepada makanan (DepkesRI, 2006)

Tangan yang kotor atau terkontaminasi dapat memindahkan bakteri danvirus patogen dari tubuh, feses, atau sumber lain ke makanan. Oleh karena itupencucian tangan merupakan hal yang pokok yang harus dilakukan oleh orangyang terlibat dalam penanganan makanan. Pencucian tangan, meskipuntampaknya merupakan kegiatan ringan dan sering disepelekan, terbukti cukupefektif dalam upaya mencegah kontaminasi pada makanan. Pencucian tangan dengan sabun dan diikuti dengan pembilasan akan menghilangkan banyak mikrobia yang terdapat pada tangan. Kombinasi antara aktivitas sabun sebagai pembersih, penggosokan, dan aliran air akan menghanyutkan pertikel kotoran yang banyak mengandung mikroba (Purnawijayanti, 2001)

Menurut (WHO, 2008) kebersihan tangan adalah ukuran utama untukmengurangi infeksi. Ada 10 langkah yang menjadi pedoman dalam WHO untukmensosialisasikan cuci tangan dengan sabun dan air. Cara mencuci tangan yangbenar adalah sebagai berikut:

1. Cuci tangan dengan air yang mengalir dan gunakan sabun. Tidak perlu harussabun khusus antibakteri, namun lebih disarankan sabun yang berbentukcairan.

2. Gosok tangan setidakknya selama 15-20 detik.

3. Bersihkan bagian telapak tangan, punggung tangan, sela-sela jari, ibu jari,ujung jari, kuku dan pergelangan tangan.

4. Basuh tangan sampai bersih dengan air yang mengalir.

5. Keringkan dengan handuk bersih atau alat pengering lain.

6. Gunakan tisu/handuk sebagai penghalang ketika mematikan air(Atikah, 2012).

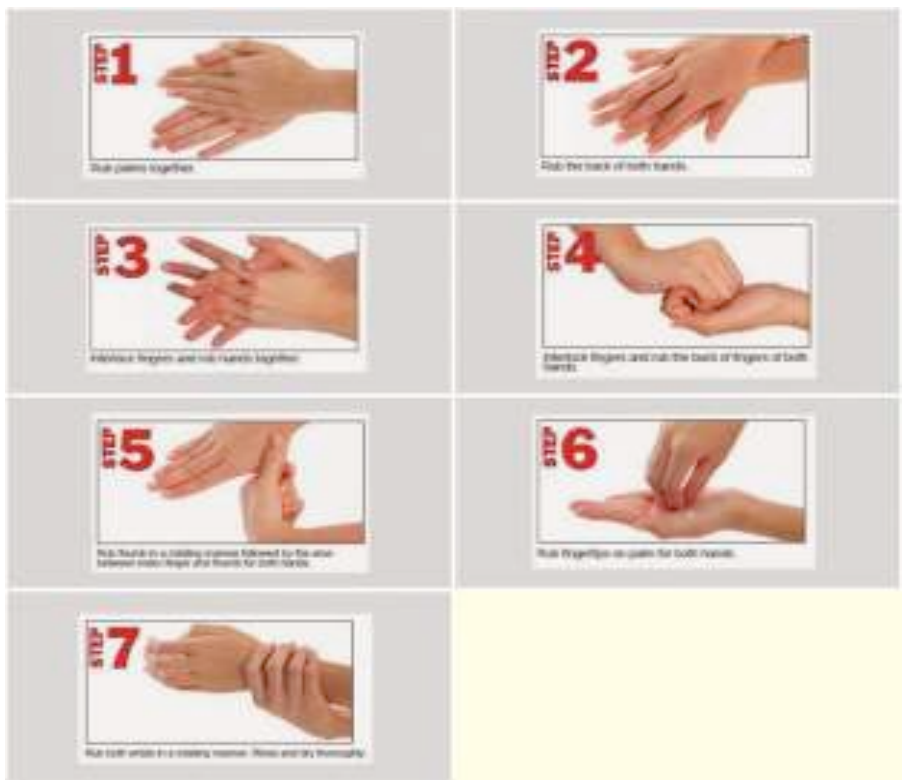

Gambar 2.1 Prosedur 7 langkah mencuci tangan

(Sumber: www.sditmadani.sch.id/2014/01/7-langkah-cara-mencuci-tangan-yang. html) 
Menurut penelitian WHO, 100 ribu anak Indonesia meninggalsetiap tahunnya karena diare. Data yang dirilis oleh Riskedas tahun 2007 menyebutkan diare termasuk salah satu dari dua penyebab kematian terbanyak pada anak-anak, selain pneumonia. Kematian pada pada anak umur 4-11 tahun yang disebabkan diare sebanyak 25,5\% dan pneumonia15,5\%. Sebanyak 40 hingga $60 \%$ diare pada anak terjadi akibat rotavirus. Biasanya virus masuk mulut melalui tangan yang terkontaminasi kotoran akibat tidak mencuci tangan.

Angka kejadian diare berkisar 200-400 diantara 1000 penduduk di Indonesia setiap tahunya, sebagian besar $(70-80 \%)$ di antaranya berusia kurang dari 5 tahun $( \pm 40$ jutakejadian). Kelompok ini setiap tahunnya mengalami lebih dari satu kali kejadian diare.

Tangan yang terkontaminasi dapat memindahkan mikroorganisme-mikroorganisme penyebab penyakit ke makanan, diantaranya yaitu mikroorganisme penyebab infeksi saluran pencernaan, saluran pernafasan maupun infeksi lainnya. Sebagai contoh yaitu Escherichia coli yang dapat menyebabkan diare dan gastroenteritis (suatu peradangan pada saluran usus), Shigella dysentriae yang mampu menyebabkan pendarahan pada usus sehingga feses yang keluar bercampur lendir dan darah, Mycobacterium tuberculosis menyebabkan infeksi pada paru (TBC) dan Ascaris lumbricoides yang dapat menyebabkan cacingan.

\section{BAHAN DAN METODE}

Kegiatan pengabdian ini dilaksanakan melalui beberapa tahapan, diantaranya:

1. Survey ke lokasi pengabdian yakni SMAN X Pekanbaru yang melibatkan tim Pengabdi guna mengetahui kondisi awal sasaran yang akan dituju sekaligus melakukan pengajuan permohnan untuk melakukan pengabdian.

2. Melakukan kegiatan penyuluhan tentang pentingnya menjaga kesehatan sekaligus melakukan pemantauan terhadap lingkungan sekolah.

3. Melakukan evaluasi /pemantauan, guna mengevaluasi pemahaman terhadap materi yang telah disampaikan.

Metode penerapan pengabdian yang dilakukan ialah berupa pemantauan kebersihan lingkungan dan penyuluhan. Pemantauan terhadap lingkungan sekolah dilakukan dengan mengamati tingkat kebersihan dilingkungan sekolah serta wawancara secara langsung dengan pihak terkait. Penyuluhan dilakukan pada anak-anak di sekolah dengan metode interaktif yang menarik bagi anak-anak. Tiga bulan setelah penyuluhan dilakukan penilaian penerapan kebersihan pada anak, ini bertujuan untuk mengevaluasi kegiatan serta melihat ada tidaknya perubahan pola kebersihan pada anak-anak yang menjadi sasaran kegiatan.

Hasil kegiatan pengabdian diharapkan dapat mengurangi resiko infeksi penyakit melalui tangan yang kotor dan dapat mengubah prilaku kebersihan diri anak-anak usia sekolah. Untuk pencapaian tujuan tersebut maka kegiatan pengabdian akan dilakukan secara berkala, untuk tahap pertama dilakukan kegiatan pendekatan terhadap anak dan pemantauan terhadap kebersihan lingkungan sekolah. Tahap kedua yaitu dilakukan pemberian informasi dan pemahaman pada anak untuk selalu menjaga kebersihan. Tahap ketiga, setelah tiga bulan akan dilakukan pemeriksaan ulang dan melihat apakah sekolah telah menerapkan pola hidu bersih dan sehat dilingkungan sekolah secara berkesinambungan.

\section{HASIL DAN PEMBAHASAN}

\section{Gambaran Umum Masyarakat sasaran}

SMAN X Pekanbaru merupakan salah satu sekolah menengah atas yang berada di kota Pekanbaru yang berlokasi tepatnya di Jalan sei mintan. Sekolah ini berdiri sejak tahun 2008. berdasarkan survey ke lapangan murid-murid yang ada dilingkungan sekolah tersebut masih perlu diberikan pemahaman terhadap sanitasi dan hiegeiene. Adapun ondisi yang ada di lapangan siswa/I masih belum membiasakan diri mencuci tangan saat akan meakukan aktifitas dan setelah melakukan aktifitas. Hal ini akan mempengaruhi tingkat kotaminasi 
terhadap beberapa mikroorganisme yang kemungkinan akan menginfeksi individu tersebut. oleh karena itu perlu diberikan pemahaman terhadap pentingnya mencuci tangan baik sebelum maupun setelah melakukan aktifitas, guna menghindari adanya kontaminan tersebut.

\section{Potensi Pengembangan}

Faktor-faktor hygiene dan sanitasi sekolah sangat ditentukan oleh beberapa faktor yaitu pegelola sekolah yang berwewenang, pegawai pengelola kebersihan sarana dan prasarana dan siswa-siswi dalam menjaga kebersihan dan keindahan, namun hal itu sering tidak berjalan lancar karena kurangnya perhatian pihak sekolah dan penerapan pendidikan hidup sehat kepada peserta didik juga biaya pemeliharaan sarana dan prasarana.

Berdasarkan dari pengamatan lapangan melalui kunjungan dapat disimpulkan bahwa keberadaan sekolah dapat dikategorikan cukup dari standar namun masih perlu banyak dilakukan pembenahan. Oleh karena itu perlu dilakukan pemahaman terhadap pelaku kepentingan untuk dapat mensosialisasikan kepada pihak terkait untuk selalu menjaga kebersihan dan menjadikan pola hidup bersih merupakan sebuah kebutuhan yang akan berdampak pada kesehatan serta berakibat pada kesejahteraan sekolah.

\section{Solusi pengembangan}

Upaya pengembangan program promosi kesehatan dan perilaku hidup bersih dan sehat yang lebih terarah, terencana, terpadu dan berkesinambungan, dikembangkan melalui Kabupaten/Kota percontohan integrasi promosi kesehatan dengan sasaran utama adalah PHBS tatanan rumah tangga (individu, keluarga, masyarakat) dan Institusi Pendidikan terutama tingkat sekolah menengah atas (SMA).

Adanya kebijakan dan dukungan dari pengambil keputusan seperti walikota, Kepala Dinas pendidikan, Kepala Dinas Kesehatan, DPRD, lintas sektor sangat penting untuk pembinaan PHBS di sekolah demi terwujudnya sekolah sehat. Disamping itu, peran dari berbagai pihak terkait (Tim Pembina dan pelaksana UKS) juga penting, sedangkan masyarakat sekolah hanya berpartisipasi dalam perilaku hidup bersih dan sehat baik di sekolah maupun di masyarakat. Penerapan PHBS ini dapat dilakukan melalui pendekatan Usaha Kesehatan Sekolah (UKS), dengan menitikberatkan kepada upaya sanitasi atau pengawasan berbagai faktor lingkungan yang dapat mempengaruhi derajat kesehatan manusia (Azwar, 2010).

\section{Tingkat ketercapaian sasaran program}

1. Penerapan PHBS di SMA NEGERI 14 Pekanbaru

2. Unit Kesehatan Sekolah selalu di jalankan

3. Promosi Kesehatan yang sangat perlu di setiap kelas

4. Memberikan contoh yang baik untuk kesehatan lingkungan dan kelas

5. Tercapainya kebersihan, keasrian, keindahan dalam lingkungan sekolah

\section{KESIMPULAN}

Berdasarkan hasil pemantauan dilapangan Personal hygiene di lingkungan sekolah menengah atas pekanbaru sudah masuk dalam aktegori cukup. Hal ini dibuktikan dengan sudah disediakannya sarana dan prasarana untuk kesehatan seperti tng sampah dan telah ada penanggung jawab dibidang kebesihan. Namun demikian masih perlu dilakukan pembenahan gunka memperoleh predikat sekolah bersih dan percontohan bagi masyarakat sekitarnya an sekolah lainnya.

Berdasarkan hasil pemantauan dilapangan perlu diberikan pemahaman terhadap seluruh anggota sekolah untuk tetap menjaga kebersihan lingkungan sekolah dan menjaga 
kebersihan individu secara rutin dan berkesinambungan guna menciptakan lingkungan sehat dan hidup sehat.

\section{UCAPAN TERIMAKASIH}

Kegiatan pengabdian ini merupakan kegiatan yang mendapatkan dana hibah pengabdian masyarakat pada tahun 2017. Ucapan terimakasih kepada Universitas Abdurrab yang telah menyediakan dana dan keada SMAN X yang telah bersedia menjadi lokasi pengabdian sehingga kegiatan berjalan dengan lancar.

\section{DAFTAR PUSTAKA}

[5]. Achmadi, U. F. (2009). Kesehatan Lingkungan. Kesehatan Masyarakat, 3, 148.

[6]. Atikah, P. (2012). Perilaku \{Bibliography\}Hidup Bersih Dan Sehat. Nuha Medika.

[7]. DepkesRI. (2006). Profil Kesehatan Indonesia, 322.

[8]. Fathonah, S. (2005). Higiene Dan Sanitasi Makanan. Semarang: Unnes Press

[9]. Kamus Besar Bahasa Indonesia Pusat Bahasa Edisi Keempat. (2008) (4th ed.). Jakarta: PT. Gramedia Pustaka Utama.

[10]. Linda, T. (2004). Panduan Pencegahan Infeksi untuk Fasilitas Pelayanan Kesehatan dengan Sumber Daya Terbatas (1st ed.). Jakarta: Yayasan Bina Pustaka Sarwono Prawirohardjo.

[11]. World Health Organization (2008). Pencegahan dan Pengendalian Infeksi di fasilitas Pelayanan Kesehatan Pedoman Ringkas.

[12]. Purnawijayanti, H. A. (2001). Sanitasi Higiene Dan Keselamatan Kerja Dalam Pengolahan Makanan. Yogyakarta: Kanisius.

[13]. Tarwoto, M. (2010). Kebutuhan Dasar Manusia Dan Proses Keperawatan. Salemba Medika. 